\title{
Operating microscope in endodontics: A systematic review
}

\author{
Carla Cabral dos Santos Accioly Lins ${ }^{1 *}$, Elma Mariana Verçosa de Melo Silva ${ }^{2}$, \\ Georgina Agnelo de Lima², Silvio Emanuel Acioly Conrado de Menezes ${ }^{3}$, \\ Rosana Maria Coelho Travassos ${ }^{3}$
}

${ }^{1}$ Center for Biological Sciences, Department of Anatomy, Federal University of Pernambuco (UFPE), Recife, Brazil

${ }^{2}$ Department of Prosthetics and Oral and Facial Surgery, Faculty of Dentistry, Federal University of Pernambuco (UFPE), Recife, Brazil

${ }^{3}$ Department of Endodontic, Faculty of Dentistry, University of Pernambuco (FOP/UPE), Recife, Brazil

Email: ${ }^{*}$ cabralcarla1@hotmail.com

Received 16 August 2013; revised 16 September 2013; accepted 2 October 2013

Copyright (C 2013 Carla Cabral dos Santos Accioly Lins et al. This is an open access article distributed under the Creative Commons Attribution License, which permits unrestricted use, distribution, and reproduction in any medium, provided the original work is properly cited.

\begin{abstract}
The objective of this study was to systematically review the literature about the use of the operating microscope in endodontics. It used sources of bibliographic cataloging electronically identified by MEDLINE via PubMed, LILACS, BBO and Scopus, using as descriptors: Endodontics, anatomy and microscopy. The selected articles were identified from the titles and abstracts, taking into consideration the following criteria: publications ranging from January 2001 to November 2012, case reports, published in an indexed journal, and publications in English language. The search showed 167 articles related to this topic, and these 21 articles met the inclusion criteria. These indicated that a higher magnification helps coronary access and the location of channels to identify and interpret the complexities of the anatomy of root canals, the removal of nuclei and intracoronary fractured instruments, to minimize trauma of surgeries in soft and hard tissues, and detect fractures and microfractures. It was found that its use has provided Endodontics with a significant improvement in vision of the operative field, offering better quality jobs and a higher success rate.
\end{abstract}

Keywords: Endodontics; Anatomy; Microscope; Systematic Review

\section{INTRODUCTION}

The knowledge of dental morphology, location, cleanli-

"Corresponding author. ness and formatting of the root canal system (RCS) are prerequisites for successful endodontic treatment. Variations in the number, morphology of roots and root canals are constant challenges to obtain satisfactory results in Endodontia [1].

Currently, in order to progress in the quality of treatment, the endodontist has been seeking support for new technologies to help you achieve success. The Operating Microscope (OM) has been used to minimize the obscurity of the operative field favoring better quality results [2].

The OM Endodontics was introduced in the early 1990s by Gary Carr [3], and their study was the basis for several other authors deepen research on its use in Odontology [2]. Its incorporation in that specialty had profound effects on how to work the endodontist; For this reason, in 1998 the American Dental Association has requested that all graduate programs in the United States should teach the use of the microscope in nonsurgical and surgical endodontics [4].

Considering this scenario, the $\mathrm{OM}$ emerges as a tool that offers many benefits such as better lighting, magnification and visualization of the operative field [5]. The high magnification helps coronary access and the location of channels to identify isthmuses, to interpret the complexities of RCS anatomy, the removal of intracoronary nuclei and fractured instruments, to minimize trauma of surgeries in soft and hard tissues, and detect fractures and microfractures [2,6]. In addition, their use gives the dental surgeon a working position more comfortable and ergonomic, reducing fatigue and stress, and conesquently, increasing work efficiency [7].

The aim of this study was to perform a systematic re- 
view of the literature on the use of OM in Endodontics, trying to focus on how this new technology is being used by experts during the execution of their treatments.

\section{MATERIALS \& METHODS}

It were performed a literature review of the past decade in scientific search engines described below: PubMed (a service of the National Library of Medicine, USA), available at electronics www.ncbi.nlm.nih.gov/pubmed, Bireme (Virtual Health Library, a specialized service of the Pan American Health Organization), specifically in the databases Medline, Lilacs, available at the website www.bireme.br and Scopus, available on the website www. info.sciverse.com/Scopus, using as descriptors in Portuguese: Endodontics, anatomy, microscopy, and as descriptors in English: Endodontic, Anatomy, Microscope.

The literature review performed was the systematic type, being adopted the following inclusion criteria: 1) publication in an indexed journal; 2) publications ranging from January 2001 to November 2012; 3) articles in English and 4) case reports. The exclusion criteria were: 1) in vitro studies; 2) works of literature review; 3) paraendodontic surgery, and 4) articles in languages of non-English origin. The articles related for the search were selected by two independent reviewers, evaluating the adopted criteria for inclusion and exclusion.

\section{RESULTS}

In databases consulted it was found in a total of 167 articles. The articles selected after methodological analysis were twenty-one. Figure 1 illustrates the design process of distribution of articles for the systematic review according to the methodology employed.

The included studies that enabled the analysis of the use of operating microscope in endodontic treatment are described in Table 1. The selected articles were organ-

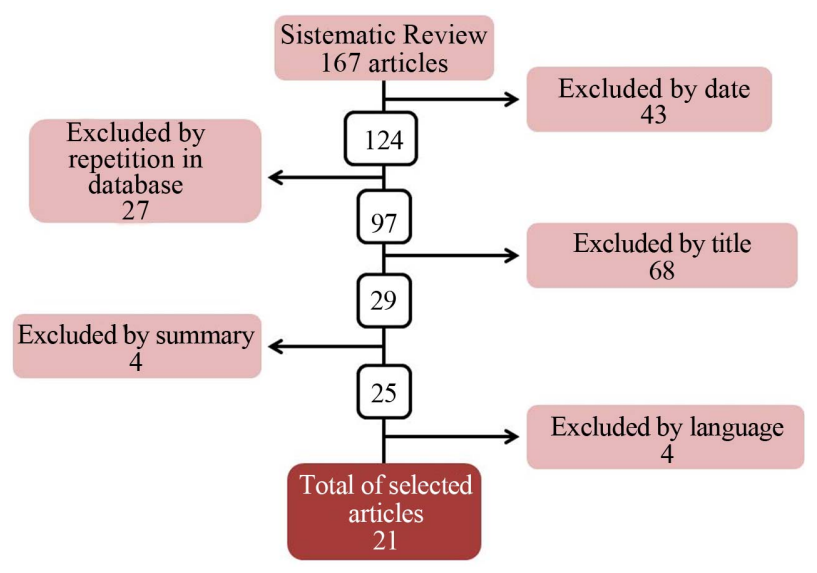

Figure 1. Distribution of articles for systematic review. ized regarding: the author, year of publication, the tooth in which was performed the endodontic treatment and the treatment stage in which the OM was employed.

After analysis of twenty-one selected articles, it was observed that in 2001 and 2009 it were not found publications which met the inclusion criteria proposed in this research. In the years 2002, 2004, 2005, 2006, 2008, occurred one publication per year, two in 2003, three in 2007 and 2010, occurring an increase in 2011 and 2012, in which four publications dealt with the subject of this study each year.

\section{DISCUSSION}

The knowledge of the complexity of the internal anatomy of the RCS is a permanent challenge to the endodontist. Proper cleaning, shaping and obturation are the requirements for successful endodontic treatment. Currently new features are available to the dental surgeon, which adds the possibility to better understand the details of the pulp cavity $[8,9]$.

The OM is a tool that has characteristics of stereoscopic vision and coaxial illumination, and those when associated with magnification facilitate the achievement of the clinical procedures [5]. The biggest impact of this innovation is that it allow an increase of $8 \mathrm{x}$ to $16 \mathrm{x}$, and may even offer higher magnifications with 32x and 40x, which are used to examine finer details $[4,5,10]$. Another important aspect is that it can be adapted to a photographic camera, a video camera and a videoprinter, which offers a best dental record and helps in patient education [2].

After analyzing the twenty-one items selected, it was observed that there was an increase in the number of publications in 2011 and 2012, of four jobs each year. This fact may be related to increased acquisition of this equipment by specialists in endodontics, contributing to a greater number of publications.

In the studies it was observed that there was no standardization in the step of the procedure or technique in which the operating microscope was used, the same being used in different stages of treatment in access to the pulp chamber [8,11-16], and the observation of the floor and location of the root canals $[8,9,13,17-26]$ in viewing artifacts inside the root canal $[8,16,27-29]$ in perforation closure [29] and the placement of the intracanal medication [19].

Regarding to the use alone or combined with other instruments such as ultrasound tips, cone beam computed tomography and optical fiber, among the authors it was not observed a consensus associated with the use of OM. In ten studies it was used only the microscope $[12,13$, $16,18,20-26]$ and in eleven the combination with other tools [8-11,14-19,23,27-19]. Emphasizing in the articles that its use was performed according to the clinical 
Table 1. Studies included in the study that allowed the analysis of the use of the operating microscope in endodontics.

\begin{tabular}{|c|c|c|}
\hline Author/Year & Dental element & Treatment step for the use of operating microscope. \\
\hline 1.Sachdeva et al., 2012 & 41 & Observation of the floor of pulp chamber and root canals location. \\
\hline 2. Silva; Zaia, 2012 & 22 & Access to the pulp chamber. \\
\hline 3. Narayana; Wallace; Nair, 2012 & 12 & Access to the pulp chamber; Placement of intracanal medication. \\
\hline 4. Nunes et al., 2012 & 12 & Visualization of artifact inside the root canal; Perforation closure. \\
\hline 5. Kaneko et al., 2011 & 12 & Access to the pulp chamber. \\
\hline $\begin{array}{l}\text { 6. Karumaran; Gunaseelan; } \\
\text { Krithikadatta, } 2011\end{array}$ & 24,14 & $\begin{array}{l}\text { Access to the pulp chamber; Observation of the } \\
\text { floor of pulp chamber and root canals location. }\end{array}$ \\
\hline 7. Kottoor; Velmurugan; Surendran, 2011 & 26 & Observation of the floor of pulp chamber and root canals location. \\
\hline 8. Ianes et al., 2011 & 46 & $\begin{array}{l}\text { Access to the pulp chamber; Observation of the floor of pulp chamber } \\
\text { and root canals location; Visualization of artifact inside the root canal }\end{array}$ \\
\hline 9. Kottoor et al., 2010 & 16 & Observation of the floor of pulp chamber and root canals location. \\
\hline 10. Karthikeyan; Mahalaxmi, 2010 & 26 & Observation of the floor of pulp chamber and root canals location. \\
\hline 11. Kottor; Sudha; Velmurugan, 2010 & 46 & Observation of the floor of pulp chamber and root canals location. \\
\hline 12. Cunha et al., 2008 & 22 & Access to the pulp chamber. \\
\hline 13. Kontakiotis; Tzanetakis, 2007 & 36 & Observation of the floor of pulp chamber and root canals location. \\
\hline 14. Tzanetakis; Lagoudakos; Kontakiotis, 2007 & 25 & Observation of the floor of pulp chamber and root canals location. \\
\hline 15. Sathorn; Parashos, 2007 & 13 & Access to the pulp chamber. \\
\hline 16. Yilmaz et al., 2006 & 16 & Observation of the floor of pulp chamber and root canals location. \\
\hline 17. Moor; Calberson, 2005 & 15 & Observation of the floor of pulp chamber and root canals location. \\
\hline 18. Jung, 2004 & 12 & Observation of the floor of pulp chamber and root canals location. \\
\hline 19. Ward; Parashos; Messer, 2003 & 16,36 & Visualization of artifact inside the root canal. \\
\hline 20. Ward, 2003 & 16 & Visualization of artifact inside the root canal. \\
\hline 21. Girsch; McClammy, 2002 & 11 & Observation of the floor of pulp chamber and root canals location. \\
\hline
\end{tabular}

experience of the operator or the need for each treatment.

When there is a deficiency in some stage of endodontic treatment is required reintervention [1]. One of the selected articles reported retreatment of upper and lower first molars, describing that the microscopic analysis was more effective in detecting and removing debris, but also allowed the location of additional channels [8]. In two other studies conducted in the upper anterior teeth the operating microscope was used for retreatment of dens invaginatus and perforation closure [16,29].

The main question regarding its use is due to high cost, and the training time required for its handling, however, the authors stated that once overcome the training time and learning, there is an improvement in clinical procedures allowing the solution of situations that would not be possible without this tool [10].

Many researchers had the same opinion that OM is helping much in Endodontics, for providing great lighting and better visualization of the operative field [12, $18,22]$. Thus, with high magnification is possible to im- prove the ability to communicate with the patient and the technical skill, thus seeing the tenuous boundaries responsible for the failure or success of the procedure [5].

\section{CONCLUSION}

The anatomical complexity of root canal system in the context of endodontic therapy is always a challenge. The results from the present study reveal that the OM has been increasingly used as an instrument of labor among endodontists. It was found that its use has provided endodontics with a significant improvement in vision of the operative field, offering better quality jobs and a higher success rate.

\section{REFERENCES}

[1] Fregnani, E. and Hizatugu, R. (2012) Endodontics: A contemporay view. 1 Edition, Santos Press, São Paulo.

[2] Feix, L.M., Boijink, D., Ferreira, R., Wagner, M.H. and Barletta, F.B. (2010) Operating microscope in Endodon- 
tics: Visual magnification and luminosity. South Brazilian Dentistry Journal, 7, 340-348.

[3] Carr, G.B. (1992) Microscopes in endodontics. Journal of the California Dental Association, 20, 55-61.

[4] Kim, S. and Baek, S. (2004) The microscope and endodontics. Dental Clinics of Nortth America. 48, 11-18. http://dx.doi.org/10.1016/j.cden.2003.12.001

[5] Calderón, M.G., Lagares, D.N., Vázquez, C.C., Gargallp, J.U. and Pérez, J.L.G. (2007) The application of microscopic surgery in dentistry. Medicina Oral Patología Oral y Cirurgía Bucal, 12, 311-316.

[6] Castellucci, A. (2003) Magnification in endodontics: The use of the operating microscopes. Practical Procedures \& Aesthetic Denistry, 15, 377-384.

[7] Marques, K.C.A., Motta Júnior, A.G., Fidel, R.A.S. and Fidel, S.R. (2008) Clinic adequation of surgical microscope on dental treatment. Revista Cientific of HCE, 2, 70-72.

[8] Ianes, C.I., Nica, L.M., Stratul, S. and Carligeriu, V. (2011) Endodontic retreatment of a mandibular first molar with five root canals: a case report. Timisoara Medical Journal, 61, 125-130.

[9] Kottoor, J., Velmurugan, N. and Surendran, S. (2011) Endodontic management of a maxillary first molar with eight root canal systems evaluated using cone-beam computed tomography scanning: A case report. Journal of Endodontics, 37, 715-719. http://dx.doi.org/10.1016/j.joen.2011.01.008

[10] Dávalos, P.M.E., Aznar, F.D.C. and Morra, D.E.F. (2010) Microscopio operatorio en endodoncia Revisión de la literatura. Acta Odontológica Venezuelana, 48, 1-6.

[11] Sathorn, C. and Parashos, P. (2007) Contemporary treatment of class II dens invaginatus. Internation Endodontic Journal, 40, 308-316. http://dx.doi.org/10.1111/j.1365-2591.2007.01205.x

[12] Cunha, R.S., Davini, F., Fontana, C.E., Miguita, K.B. and Bueno, C.E.S. (2011) The microsonics concept: Maxillary first molar with five root canals: Case report. South Brazilian Dentistry Jounal, 8, 231-235.

[13] Karumaran, C.S., Gunaseelan, R. and Krithikadatta, J. (2011) Microscope-aided endodontic treatment of maxillary first premolars with three roots: A case series. Indian Journal of Dental Research, 22, 706-708. http://dx.doi.org/10.4103/0970-9290.93460

[14] Kaneko, T., Sakaue, H., Okiji, T. and Suda, H. (2011) Clinical management of dens invaginatus in a maxillary lateral incisor with the aid of conebeam computed tomography: A case report. Dental Traumatology, 27, 478-483. http://dx.doi.org/10.1111/j.1600-9657.2011.01021.x

[15] Narayana, P., Hartwell, G.R., Wallace, R. and Nair, U.P. (2012) Endodontic clinical management of a dens invaginatus case by using a unique treatment approach: A case report. Journal of Endodontics, 38, 1145-1148. http://dx.doi.org/10.1016/j.joen.2012.04.020

[16] Silva, E.J.N.L. and Zaia, A.A. (2012) Open apex Type III dens invaginatus: A rare case report of an endodontic retreatment with an anatomical redesign. General Dentistry,
60, 389-392.

[17] Girsch, W.J. and McClammy, T.V. (2002) Microscopic removal of dens invaginatus. Journal of Endodontics, 28, 336-339.

http://dx.doi.org/10.1097/00004770-200204000-00020

[18] Jung, M. (2004) Endodontic treatment of dens invaginatus type III with three root canals and open apical for amen. International Endodontic Journal, 37, 205-213. http://dx.doi.org/10.1111/j.0143-2885.2004.00778.x

[19] Moor, R.J.G. and Calberson, F.L.G. (2005) Root canal treatment in a mandibular second premolar with three root canals. Journal of Endodontics, 31, 310-313. http://dx.doi.org/10.1097/01.don.0000140578.36109.c0

[20] Yilmaz, Z., Tuncel, B., Serper, A. and Calt, S. (2006) Cshaped root canal in a maxillary first molar: A case report. International Endodontic Journal, 39, 162-166. http://dx.doi.org/10.1111/j.1365-2591.2006.01069.x

[21] Tzanetakis, G.N., Lagoudakos, T.A. and Kontakiotis, E.G. (2007) Endodontic treatment of a mandibular second premolar with four canals using operating microscope. Journal of Endodontics, 33, 318-321. http://dx.doi.org/10.1016/j.joen.2006.08.006

[22] Kontakiotis, E.G. and Tzanetakis, G.N. (2007) Four canals in the mesial root of a mandibular first molar. A case report under the operating microscope. Australian Endodontic Journal, 33, 84-88. http://dx.doi.org/10.1111/j.1747-4477.2007.00068.x

[23] Kottoor, J., Velmurugan, N., Sudha, R. and Hemamalathi, S. (2010) Maxillary first molar with seven root canals diagnosed with cone-beam computed tomography scanning: A case report. Journal of Endodontics, 36, 915-921. http://dx.doi.org/10.1016/j.joen.2009.12.015

[24] Karthikeyan, K. and Mahalaxmi, S. (2010) New nomenclature for extra canals based on four reported cases of maxillary first molars with six canals. Journal of Endodontics, 36, 1073-1078. http://dx.doi.org/10.1016/j.joen.2009.12.001

[25] Kottoor, J., Sudha, R. and Velmurugan, N. (2010) Middle distal canal of the mandibular first molar: A case report and literature review. International Endodontic Journal, 43, 714-722. http://dx.doi.org/10.1111/j.1365-2591.2010.01737.x

[26] Sachdeva, G.S., Malhotra, D., Sachdeva, L.T., Sharma, N. and Negi, A. (2012) Endodontic management of mandibular central incisor fused to a supernumerary tooth associated with a talon cusp: A case report. International Endodontic Journal, 45, 590-596. http://dx.doi.org/10.1111/j.1365-2591.2012.02029.x

[27] Ward, J.R. (2003) The use of an ultrasonic technique to remove a fractured rotary nickel-titanium instrument from the apical third of a curved root canal. Australian Endodontic Journal, 29, 25-30. http://dx.doi.org/10.1111/j.1747-4477.2003.tb00492.x

[28] Ward, J.R., Parashos, P. and Messer, H.H. (2003) Evaluation of an ultrasonic technique to remove fractured rotary nickel-titanium endodontic instruments from root canals: Clinical cases. Journal of Endodontics, 29, 764-767. http://dx.doi.org/10.1097/00004770-200311000-00018 
[29] Nunes, E., Silveira, F.F., Soares, J.A., Duarte, M.A. and Soares, S.M. (2012) Treatment of perforating internal root resorption with MTA: A case report. Journal of Oral
Science, 54, 127-131.

http://dx.doi.org/10.2334/josnusd.54.127 